\title{
Restrictions of private owner's rights to a land plot
}

\author{
Dmitry Bobrov ${ }^{1 *}$ \\ ${ }^{1}$ Irkutsk State University, Law Institute, Ulan-Batorskaya str., 10, Irkutsk, 664082, Russia
}

\begin{abstract}
This article discusses restrictions on the rights of the owner of a land plot in the Russian legislation related to environmental protection. Urgency of the issues of restricting the rights of a private owner to a land plot lies in the size of limits of such restrictions in order to comply with the interests of third parties, as well as to preserve the environment. This reason is becoming more popular and often proposals are being considered to increase measures aimed at protecting nature with a revision of the owner's exclusive rights to a land plot. During the study, such suggestions were highlighted as: possibility of the land plot owner to initiate the impossibility of using the land for its intended purpose in connection with classifying such a land as land that authorities are required to withdraw in accordance with the law; provide the owner of the land plot, including common owners, the right to dispose of tree-shrub vegetation located on such a plot. In connection with selection of proposals, it was concluded that it is necessary to amend Russian legislation to the legal acts regulating the above mentioned relations. We believe that in the era of global transformations, these proposals will be timely, improve public relations and meet the requirements for protecting both the economic rights of owners and the environment.
\end{abstract}

\section{Introduction}

In modern realities, issues are increasingly being raised regarding the achievement of a balance between economic development and environmental protection. They arise, first of all, due to the increasing involvement of natural objects in economic and social turnover of the country. No doubt, the use of new types and methods of using natural resources contributes to the development of both the country's economy and the entrepreneurial activities of organizations and individuals. However, the irrational use of natural resources creates conflicts in many areas of society and jeopardizes human life and health, and the entire ecosystem.

The main way to solve the above mentioned problems is to transform the thinking of a person, attitude to the conduct of economic activity and the use of natural objects. Proper legislative regulation is a determinant for creating the necessary balance between economy and ecology.

*Corresponding author: a.copytowa@yandex.ru 
The purpose of the work is to identify existing in the law "protective" duties of the land plot owner in relation to the environment; and to formulate proposals to amend existing legislation, dictated by the transformation of climatic, economic and social fields, to improve such areas of life as environmental protection and protection of property rights.

The novelty of the study lies in development of proposals to expand capabilities of the private owner in case of land acquisition for state and municipal needs, as well as to regulate relations related to the issue of disposing of trees and shrubs located on the owner's land.

\section{Methods}

The empirical basis of the work includes the past and the current legislation of the Russian Federation, using the judicial practice prevailing in various regions of the country, as well as taking into account foreign experience in legal regulation.

The methodological basis of this article includes: analysis, synthesis, analogy, dialectical-materialistic, system-functional, historical, linguistic, technical-legal and comparative legal methods.

Analysis, synthesis and system-functional methods allowed drawing certain conclusions in understanding the essence of the mechanism of ownership, and limits of their limitations. Dialectics allowed us to push away from general theoretical ideas and find a place for private property in general system of civil law objects. The historical method provided an opportunity to study the experience of Russian legislation of earlier years. The linguistic method brought an understanding of legal acts of foreign countries. Analogy, technical and legal and comparative legal methods made it possible to study the norms of Russian and foreign legislation and to deduce the most important features and conclusions regarding the research topic.

\section{Results}

The The right of ownership is an absolute property right, it contains the maximum number of property rights. However, the law enshrines numerous restrictions on the right of ownership, this is most obvious when it comes to ownership of natural objects, since they are of particular importance to society and, as a result, to the state. So, part 2 of article 36 of the Constitution of the Russian Federation stipulates that "the ownership, use and disposal of land and other natural resources are carried out by their owners freely, if this does not harm the environment and does not violate the rights and legitimate interests of other persons." Thus, the main act of the state establishes only two, but very capacious restrictions that impede the freedom of the owner, these are: damage to the environment and violation of the rights and legitimate interests of other people.

Art. 209 of the Civil Code of the Russian Federation repeats the Constitution in many respects, however, it adds another limitation - the owner has the right to take any actions that are not contrary to the law and other legal acts. The analysis of only two rules of law clearly demonstrates the existence of restrictions formulated broadly on the one hand, and on the other hand, their list is open and can be supplemented and specified.

The reasons for this approach of the legislator rightly noted by M.M. Brinchuk are the difference between natural objects from other objects of the social sphere. "The global trends in the regulation of relations of private ownership of natural objects and resources, including land, include introduction of environmental restrictions in the exercise of powers of the owner, bearing in mind the highly public nature of the object not only of state but also of private property. Therefore, land and other natural resources are not only publicly, 
but also privately owned, and can be used only taking into account the public interest in maintaining environmental well-being. " [1] In this article, we will consider some of the duties and restrictions of the owner of a natural object established with the aim of preserving public interests and natural objects themselves.

a. Private land withdrawal

A land plot is the most common object of civil rights, in comparison with other natural objects. The Land Code identifies land categories and types of permitted use of land. The law states that in private ownership there may be agricultural land, some types of land in settlements, water resources, specially protected territories and objects. Depending on the category and type of permitted use, certain obligations and restrictions are established for the owner.

Establishment of categories and types of land is important due to the need for their rational use, including with a view to preserving the environment. In the Art. 42 of the Land Code of the Russian Federation, following obligations of the owner are stipulated: to use the land in accordance with their intended purpose in ways that should not harm the environment, including land as a natural object; take measures to protect land, forests, water bodies and other natural resources, including fire safety measures; prevent pollution, depletion, degradation, spoilage, destruction of lands and soils and other negative impacts on lands and soils. In case of non-compliance with the intended purpose, the owner may be subject to administrative liability. According to Art. 6 of the Federal Law "On the turnover of agricultural land", if the owner uses the agricultural land for other purposes for three years, his plot may be seized in a judicial proceeding. If it is established that, in use, the owner of the land plot significantly reduced the fertility of agricultural land soils or caused damage to the environment, and did not eliminate the indicated violations after the appropriate administrative punishment was imposed, then the land plot can be forcibly removed in court. These rules do not apply to cases when a land plot is subject to a mortgage, or a bankruptcy case has been initiated against the owner. These cardinal measures emphasize the special importance of agricultural land, both for humans and for the country's ecosystem.

Civil Code in Art. 284 duplicates the norm on the seizure of agricultural land in case of its misuse, and also extends this list to the lands where housing or other construction is planned. Thus, if, according to the use of the plot, any construction is implied, then the owner has the obligation to start it within three years, otherwise, according to the law, land may be withdrawn for the above mentioned reasons. Based on this, the owner of a horticultural plot will be required to complete the construction within the prescribed time limit, otherwise he will face an administrative fine and may be seized. Apparently, the legislator wanted to establish a sanction in form of an exemption in case of repeated violation of misuse, or thus expand the range of possible sanctions the owner may be subject to. However, in Art. 8.8 of the Code of Administrative Offenses such an alternative punishment is not indicated, which creates the possibility of a double - administrative and civil punishment for the same offense, which is not correct.

The Leninsky District Court of the Tula Region in the case No. 2-209 / 2019 of February 20, 2019 satisfied the claims of the Ministry of Property and Land Relations of the Tula Region against V. Atamanov regarding seizure of the land. Atamanov V.I. undertook to eliminate the violation in form of non-use of the land plot intended for housing construction. Later, a state inspector in the Tula region on the use and protection of land conducted an audit of compliance with land legislation in relation to Atamanov V.I. During the audit, it was found that the land category of land of settlements, permitted use for housing construction, belongs to the right of ownership Atamanov V.I. Upon examination, it was found that the above mentioned land has a complex configuration. On several sides of the land is a country road. On one side of the land is overgrown with weeds 
and trees. By Atamanov V.I. no documents were submitted confirming the elimination of the identified violation expressed in the non-use of the land plot, as well as documents confirming the adoption of measures to eliminate the identified violation. Magistrate's order found Atamanov guilty of an administrative offense, under Part. 25 Article. 19.5 Administrative Code of the Russian Federation. He stated that it is impossible to objectively use the disputed land for its intended purpose, namely for housing construction, and recognized the lawsuit.

If it was impossible to develop the land, the defendant should have fenced and sold it, but if it was used as a road and prevented the passage of other owners, then according to Art. 49 of the RF Labor Code, the formation of a local highway is a case for withdrawing a site for municipal needs with the provision of compensation. However, only the executive bodies of the Russian Federation, its constituent entities, as well as local authorities have the right to decide on the seizure of a land plot. Only a certain circle of organizations approved by Decree of the Government of the Russian Federation of May 6, 2015 No. 442 "On Approving the List of Organizations Eligible to Request Applications for the Seizure of Land for Federal Needs", and with whom agreements were concluded on the integrated development of the territory at the initiative of the local government following the results of the auction. Having analyzed the above resolution, it should be noted that only organizations that have received a license to carry out activities important to the state, or natural monopolies, can apply for. Therefore, the circle of persons entitled to petition is very limited and dependent on the authorities. Thus, the law does not allow other persons to even apply for the redemption of their land. Moreover, part 9 of article 56.4 of the RF Labor Code establishes that the application of an unauthorized person should be returned without consideration.

Returning to the above mentioned situation of Atamanov V.I., it should be noted that due to the non-use of the land by the owner, the type of permitted use of which allows construction, the state authorities, despite the objective impossibility of such use, seized the land by the court without redemption. This situation in the law allows authorities to unreasonably save to the detriment of the interests of the owner, which directly contradicts part 3 of art. 35 of the Constitution of the Russian Federation stating that "the compulsory alienation of property for state needs can be made only subject to preliminary and equivalent compensation."

To prevent the occurrence of such situations, we offer to provide the owner of such a natural object with the right to apply for an exemption for state and municipal needs. In this regard, add to the list of persons who may apply, enshrined in Part 1 of Art. 56.4 of the Land Code of the Russian Federation, owners of land plots whose land may be withdrawn in accordance with the law.

b. Ownership of trees and shrubs

The question of right to dispose of private forest resources located on a land plot is ambiguous. Part 2, Art. 261 of the Civil Code of the Russian Federation establishes that "unless otherwise provided by law, the ownership of a land plot extends to the surface (soil) layer and water bodies located on the boundaries of this plot". Based on this interpretation, it is difficult to unequivocally say whether the owner has rights to woody and shrubbery, however, since the legislator did not separately identify forest stands as other natural objects, one has to lean toward a negative decision. Moreover, in 2006, paragraph 2 of Part 2 of Art. 40 of the Labor Code unequivocally fixed the possibility of disposing of perennial plantations, which indicates that the owner of the land does not have the right to trees and shrubs.

At the same time Art. 40 of the LC RF states that the owner has the right to carry out cultural work in accordance with the permitted use. The establishment of such a norm is dictated by the fact that the legislator seeks to balance the economic interests of land users 
with the interests of the whole society through the legal protection of natural objects. Cultural works - a set of measures to clean the surface and radically improve the physicochemical and biochemical properties of soils involved in agricultural circulation, as well as increase their fertility. Cultural works include: liberation of land from trees and shrubs, stumps, buried wood, stones, etc. ". Thus, it can be said with confidence that the owner has the right to clear wood and shrub vegetation on agricultural lands in order to increase fertility. Based on the foregoing, in other cases, any perennial plantation cannot be cut down even by the owner of the site.

The legislation has administrative and criminal sanctions in case of illegal logging, damage to forest stands or unauthorized digging of trees, shrubs, vines in the forests. On their basis violators are held accountable. However, there is Resolution of the Plenum of the Supreme Court of the Russian Federation of October 18, 2012 No. 21 "On the application by the courts of the legislation on liability for violations in the field of environmental protection and nature management", where in paragraph 15 it is stated that "they do not relate to the subject of these crimes (Articles 260, 261 of the Criminal Code of the Russian Federation), in particular, trees, shrubs and vines growing on agricultural lands (with the exception of forest stands intended to ensure the protection of lands from the effects of negative (harmful) natural, anthropogen and man-made phenomena), on personal land plots, on land plots provided for individual housing, garage construction, personal subsidiary plots, gardening, animal husbandry and horticulture, in nurseries, nurseries of fruit, berries, ornamental and other crops, and also wind, windbreak, dead trees, unless otherwise provided by special regulatory legal acts." Paragraph 22 also states that "the main criterion for distinguishing between criminally punishable illegal logging (part 1 of article 260 of the Criminal Code of the Russian Federation) and illegal logging, for which liability is provided for in article 8.28 of the Code of Administrative Offenses, is a significant amount of damage caused by the infringement". Thus, this decree cancels sanctions on individuals to cut trees, shrubs, and vines on certain categories of land, but does not stipulate anything about the ban on these actions.

In practice, the courts are actively guided by the above mentioned Plenum Resolution. So, the Magistrate's Court of Vladivostok in case No. 5 - 806/2018 of July 4, 2018 terminated the case of an administrative offense under Part 2 of Art. 8.28 of the Code of Administrative Offenses. According to the circumstances of the case, G. felled a rotten tree on a plot belonging to him by right of ownership. Referring to the Decree of the Plenum of the Supreme Court of the Russian Federation of October 18, 2012 No. 21, the court ruled that felling a tree located on a land plot does not constitute an offense due to the fact that these actions are not the subject of an offense.

Restrictions on the rights of owners, strengthened since 2006, were dictated by the desire to save forests from destruction, because according to statistics, the proportion of illegal logging of forest stands amounts to $95 \%$ in the structure of all environmental crimes. However, the percentage of cases of cutting forest stands by owners in their areas is a rare occurrence, and the damage to the environment is very low. Most owners make a saw cut of a tree in case of a threat to life and health of people or in order to prevent damage to property due to the inclination of the tree. The tree, in turn, begins to bend due to a decrease in its bearing capacity, which occurs due to washing out the roots, decay, lightning or other reasons.

At the regional level, the regime of tree-shrubby objects is regulated, as a rule, in favor of not burdening the owner with such objects. Based on the meaning of paragraph 7 of Ch. IX Decisions of the Pskov City Council dated April 29, 2011 No. 1692 "On the Approval of the Rules for Improvement, Sanitary Maintenance and Gardening of the City of Pskov" for individuals and legal entities holding a land plot on a private property right, there is no need to obtain permission to order landscaping objects. 
The decision of the Volgograd City Council of October 21, 2015 No. 34/1091 "On the Approval of the Rules for Improvement of the Territory of the Volgograd City District" fixed the problems of disposing and protecting green spaces exclusively for land plots that are in municipal ownership and in lands located in common areas.

So until recently, in the city of Irkutsk, the Decision of the Duma of the city of Irkutsk dated November 25, 2004 No. 004-20-050035 / 4 "On the Rules for Creation, Maintenance and Protection of Green Plants in the City of Irkutsk" was in force. According to this Decision any person who has in the city the green space on his plot was obliged to plant it only according to certain rules, to ensure protection, maintenance and coordinate its demolition with the administration. But by the Decision of the Duma of Irkutsk dated December 3, 2018 No. 006-20-510815 / 8 "On the organization of greening the territory of the city of Irkutsk" new rules were adopted, according to which, the fixed measures for creation, maintenance of protection and demolition apply only to green areas of common use. Thus, private owners of land located in Irkutsk are not required to comply with these requirements, but owners of apartment buildings are subject to this decision.

Let us turn to international experience. Art. 552 of the French Civil Code states that "the right of ownership of land includes the right of ownership of what is on and under the ground." From the meaning of paragraph 1067 of the Civil Code of the Czech Republic, it should be concluded that the tree belongs to the one on whose land the trunk grows. Art. 390 of the Civil Code of Spain stipulates that the owner of the land is obliged to clean the tree if it threatens to fall and can damage other people's property or passers-by on public or private roads. From the examples we have given, the idea of unity of the land plot and everything located on its surface is clearly traced.

An analysis of modern Russian and foreign legislation allows us to conclude that it is necessary to streamline and transform the national regulation of relations in the field of the volume of property rights to a land plot. It is necessary to give private owners of the land the right to dispose of tree and shrub plantings, except for those listed in the Red Book. This will allow owners to use the surface of the land plot in a more mobile and efficient way, without affecting especially rare species of trees that are on the verge of extinction. The rights of persons who take land for temporary possession and use should also be respected. Therefore, we propose to make part 2 of Art. 40 of the RF Land Code, which discloses property on a land plot, the following provision: "tree and shrubbery vegetation, unless it transfers the land to lease, permanent (unlimited) use, lifetime inheritable possession or free use, or such vegetation is listed in Red Book. "

We propose the same principle to be fixed for owners who have trees and shrubs on the basis of common property. For example, the owners of an apartment building, on the basis that they own the land where this house is located, with elements of landscaping, will be able to demolish an emergency tree that threatens the life and health of people, as well as their property, without receiving permission from the city administration; or to plant new trees and bushes in order to increase the level of ecological well-being and improvement of the territory. Therefore, we propose to add to Art. 36 RF LC the following provision: "The owners of premises in an apartment building own, use and manage the elements of landscaping and improvement on the basis of decisions of the owners of premises in an apartment building adopted at the general meeting of such owners."

\section{Discussion}

Debatable is in Russian law the issue of differentiation and correlation of such concepts as forest, shrubbery and perennial plantings, as well as their legal regime in the hands of the owners. In pre-revolutionary times, it followed from the law that the forest is an integral part or ownership of land, so civil law did not have the problem of dividing the legal regime 
of land and what grows on it. Already in Soviet times, scientists developed the definition of the forest as a kind of separate object, so its legal fate can be realized in a different way than on a land plot. R.K. Gusev came to the conclusion that "the legal concept of "forest" can be represented as a combination of tree-shrub organisms growing on the earth that meets certain quantitative and qualitative forestry requirements and is recognized by the forest in the established manner." [2] V.F. Gorbov formulated following definition: "Forest is an independent and reproducible object of nature and part of the natural (ecological) environment, an object of exclusive state ownership in form of a specific, interconnected collection of trees, shrubs, other plants, which is a sphere of forestry and forest industry, a source production of wood and other forest products, which has protective, water protection, health, sanitary and aesthetic functions, influence environmentally friendly, located on specially allocated lands and registered as forest in state accounting documents".

The situation is more complicated with distinction between trees and shrubs and perennial plantings. Since environmental and urban standards characterize the above mentioned definitions in the context of "landscaping" and "green zone", it is difficult to draw parallels between them. In turn, Yu.I. Shupletsova believes that perennial plantings are those plantings that do not require annual renewal in the same place and cannot be moved without their death or significant damage, that is, perennial trees in the adult state are primarily perennial [3]. Many researchers identify these concepts by substituting them for each other, since tree-shrub vegetation has existed in nature for several years, however, in such cases plants that may also exist for more than one year are not taken into account, but they are rarely mentioned in legal science.

A serious issue is the legal regime of these natural objects. Back in 1984 A.A. Ryabov in his doctoral work wrote that, based on the legislation of the USSR and the Union republics, tree and shrub vegetation are not part of the country's unified land fund, but the law did not regulate the assignment to any other property or type of use. The previous Forest Code resolved this dispute towards the owner, including the private one.

\section{Conclusion}

Thus, several gaps in Russian legislation were highlighted that impede the normal implementation of the rights of a private owner to a land plot. Taking into account the revealed results of the study, we believe that we should recommend the legislator to amend the above mentioned regulatory legal acts. We believe that in the era of global transformation, these proposals will be timely, improve public relations and meet the requirements for protecting both economic rights of owners and environment.

\section{References}

1. M. M. Brinchuk, Correl. Envir. Law branch. Probl. Theor. Pract. 7, 27-28 (2009)

2. R.K. Gusev, Legal problems of managing the state forest fund of the USSR: Abstract dis. for the degree of candidate of legal sciences, (1971)

3. Yu.I. Shupletsova, Property Rights to Natural Resources: Public and Private Interests (2007)

4. S. I. Arkhipov, Probl. Owner. St. Peter. 1, 46, 2007

5. O. I. Krassov, Land law (2014)

6. U. Filatova, N. Semeryanova, E. Vasilev, Technological and engineering equipment as an object of civil rights: intersectoral aspect, DOI: https://doi.org/10.1051/e3sconf/20199108064 
7. M. I. Braginsky, V.V. Vitryansky, Contract law. Book One: General Provisions of (2011)

8. S. A. Bogolyubov, Land law: a textbook for academic undergraduate (2016)

9. V.E. Lukyanenko, E.I Pudlina, Spec. Norms-Prohib., Norms-Restrict. Norms Stop Circul. Land Other Natur. Obj. 8, 79-80, (2009)

10. I. A. Konforkin, Criminal liability for illegal felling of forest stands (2010)

11. A. Yu. Petrov, O.V. Dubrovin, Withdr. Land Plot Sanct. Violat. Land Tax Legisl, 7, 104 (2012)

12. V. Lez'Er, , N Semerianova,. Et al. E3S Web of Conferences 2019, 110,02093, DOI: $10.1051 / \mathrm{e} 3$ sconf $/ 201911002093$

13. V. Lez'Er, , Semeryanova, N., Kopytova, A., I. Kvach, E3S Web of Conferences, 2019, 110,02094, DOI: 10.1051/e3sconf/201911002094

14. U. Filatova, N. Semeryanova..et al. 2019, E3S Web of Conferences 91,08071, DOI: $10.1051 / \mathrm{e} 3$ sconf $/ 20199108071$

15. R. Kolobov, U. Filatova, et al. E3S Web of Conferences 2019, 110,02095, DOI: $10.1051 / \mathrm{e} 3$ sconf $/ 201911002095$

16. A. Kopytova, MATEC Web of Conferences 106, 08056 (2017) DOI: 10.1051/matecconf/201710608056

17. M. Gravit, O. Zybina, A. Vaititckii, A. Kopytova, IOP Conference Series: Earth and Environmental Science 90 (1), 012103 (2017) DOI: 10.1088/1755-1315/90/1/012103 